\title{
CHAPTER I INTRODUCTION
}

1.1 Background

1.2 Objectives

1.3 Instrumentation

1.4 Theory

CHAPTER II PREDICTIONS

2.1 Geologic Environment

2.2 Phenomenology and Containment

2.3 Seismic Effects

CHAPTER III ANALYSIS AND INTERPRETATION

40

3.1 Phenomenology and Containment

40

3.2 Seismic Effects

CHAPTER IV CONCLUSIONS AND RECOMMENDATIONS

APPENDIX A

APPENDIX

\section{TABLES}

2.1 Comparison of Physical Properties of

Shoal and Climax Stock Granites

2.2 Predictions of Amplitudes of Ground Motion

3.1 Peak Surface Particle Acceleration in g's 66

3.2 Peak Surface Particle Displacement in Centimeters

3.3 Peak Surface Particle Velocity in $\mathrm{cm} / \mathrm{sec}$

3.4 Stations Used in Comparison of Data Measured Parallel and Perpendicular to Direction of Major Faulting

3.5 Ratio of $\frac{\mathrm{u}^{2}}{\mathrm{ad}}$

1.1 Locations of Instrument Stations 74

1.2 Cross Section A-A'-A"

1.3 Geologic Map 